\title{
Peran Freelance Marketplace dan Media Sosial dalam Online Gig Economy Jasa Profesional
}

\author{
The Roles of Freelance Marketplaces and Social Media in Facilitating \\ Professional Services Online Gig Economy \\ Nina Mia Aristi ${ }^{1}$, Ahmad R Pratama ${ }^{2}$ \\ ${ }^{1}$ Program Studi Informatika - Program Magister, Universitas Islam Indonesia \\ ${ }^{2}$ Jurusan Informatika, Universitas Islam Indonesia \\ E-mail: ${ }^{1}$ nina.aristi@ students.uii.ac.id, ${ }^{2}$ ahmad.rafie@uii.ac.id
}

\begin{abstract}
Abstrak
Freelance marketplace adalah suatu jenis platform online gig economy yang mengkhususkan fungsinya untuk menghubungkan penyedia jasa dan pihak yang membutuhkan dalam jual beli jasa profesional. Pada praktiknya, jual beli jasa profesional juga terlaksana melalui media sosial yang cara kerjanya berbeda dengan freelance marketplace. Melalui survei yang disebarkan di media sosial, peneliti mengumpulkan data dari 280 pelaku gig economy di bidang jasa profesional yang menggunakan freelance marketplace dan media sosial, untuk mengetahui perbedaan kedua platform tersebut dalam perannya memfasilitasi kegiatan gig economy. Melalui analisis statistik deskriptif dan inferensial, peneliti menemukan bukti adanya perbedaan peran yang dimainkan oleh kedua platform tersebut. Freelance marketplace berperan memasarkan jasa pekerja gig Indonesia ke pasar internasional dan cenderung digunakan oleh penyedia jasa yang lebih berpengalaman dengan harga jual per-gig yang lebih tinggi dibanding di media sosial. Sementara itu, meski harga jual per-gig-nya cenderung lebih rendah, media sosial berperan besar dalam pemasaran di dalam negeri dan cenderung lebih cocok untuk penyedia jasa pemula. Secara umum, freelance marketplace dan media sosial sama-sama berperan membuka lapangan kerja baru yang berpotensi menjadi mata pencaharian utama. Selain itu, keduanya juga memberikan kesempatan bagi siapa saja untuk menjadi penyedia jasa tanpa keharusan adanya gelar akademik untuk berkarir di bidang ekonomi kreatif.
\end{abstract}

Kata kunci: online gig economy, freelance marketplace, media sosial, jasa profesional

\begin{abstract}
A freelance marketplace is a type of online gig economy platform specializing in connecting profesional service gig workers to anyone in need. In practice, professional services tansactions are also done through social media albeit working differently from freelance marketplaces. An online survey was conducted through social media to collect data from 280 professional service gig workers to investigate the differences between the two platforms regarding their roles in facilitating online gig economy activities. Using descriptive and inferential statistical analysis, we found evidence of different roles played by the two platforms. Freelance marketplaces play an important role in marketing Indonesian gig workers to the international market and tend to be used by more experienced service providers with higher gig price than on social media. While the gigs tend to be cheaper on social media, this platform still plays a major role in domestic marketing and is more suitable for early-career gig workers. In general, both freelance marketplaces and social media opened up new job opportunities, which have potential to serve as the main source of income for many gig workers. It also provides job opportunities for anyone without any specific academic degree to start a career in creative economy industries.
\end{abstract}

Keywords: online gig economy, freelance marketplace, social media, professional services 


\section{PENDAHULUAN}

Perkembangan teknologi memungkinkan orang untuk bekerja sebagai pekerja mandiri, dari lokasi manapun yang mereka inginkan, tanpa harus datang ke kantor. Terlebih lagi dalam masa pandemi COVID-19 yang berdampak luas terhadap sektor ekonomi. Sedikitnya 1,7 juta penduduk Indonesia kehilangan pekerjaan akibat pandemi tersebut [1]. Keadaan tersebut, dikombinasikan dengan diterapkannya kebijakan physical distancing dan work from home, dapat memancing minat masyarakat untuk beralih menjadi pekerja mandiri. Salah satu jenis pekerja mandiri adalah pekerja mandiri yang pekerjaannya tergantung akan adanya permintaan dari pembeli. Pekerjaan seperti inilah yang disebut dengan gig-economy. Hal tersebut telah mendorong terciptanya model bisnis baru berupa organisasi bisnis yang menjalankan usaha sebagai penyedia layanan yang menjembatani penyedia jasa dan pengguna jasa [2]. Organisasi bisnis atau perusahaan tersebut kemudian membuat platform berbasis online yang menyediakan sarana untuk mempertemukan pembeli dan penyedia jasa. Platform online tersebut biasanya mengkhususkan operasinya pada satu jenis jasa saja. Jasa profesional adalah jasa berupa keahlian dalam menyelesaikan suatu project. Biasa project tersebut tidak menghasilkan produk berupa barang fisik. Contoh dari jasa profesional adalah jasa coding, konsultan, penulisan , penerjemahan, desain, dll [3].

Platform gig economy yang mengkhususkan fungsinya sebagai wadah pemasaran jasa profesional disebut freelance marketplace. Freelance marketplace merupakan sarana yang menghubungkan secara langsung penyedia jasa profesional lepas dengan pihak yang membutuhkan jasa dalam rangka menyelesaikan proyek mereka. Contoh dari freelance marketplace adalah situs-situs seperti Upwork, Sketchmob, Fiverr, dll.

Di samping platform yang dibangun khusus untuk memfasilitasi gig economy, para penyedia jasa profesional juga memanfaatkan media sosial sebagai sarana promosi dan untuk menggaet client. Media sosial sendiri adalah sarana yang dapat berperan penting dalam mempromosikan bisnis kepada konsumen, karena pihak penjual dapat meningkatkan kesadaran konsumen terhadap brand bisnis [4]. Hal tersebut bisa dibuktikan dengan banyaknya grup-grup Facebook yang berisikan komunitas freelancer dari bidang keahlian yang sejenis [5]. Sebagai contoh, pada media sosial Facebook, untuk jasa profesional ilustrasi saja, grup Commission Corner Indonesia dan Commission Art Center Indonesia, masing-masingnya memiliki anggota lebih dari 27.000 orang. Hal ini semakin menegaskan potensi dari gig economy untuk jual beli jasa profesional. Akan tetapi media sosial, dikarenakan bukan platform khusus yang diciptakan untuk memfasilitasi proses jual beli jasa, memiliki perbedaan dengan freelance marketplace jika digunakan sebagai fasilitas gig economy.

Penelitian mengenai online gig economy di Indonesia pernah dilakukan oleh Ari Auditianto, Dian Fatmawati, dan Onat Kibaroğlu yang membahas mengenai gig economy Indonesia jenis jasa transportasi $[6,7,8]$ yang sifat gig economy-nya berbeda dengan gig economy jasa profesional karena layanannya yang berupa aktivitas fisik. Sedangkan untuk jenis gig economy jasa profesional Indonesia, pernah dilakukan oleh A. Labib Fardany Faisal yang mengumpulkan informasi mengenai penyedia jasa profesional Indonesia dari sembilan freelance marketplace (Upwork, Fiverr, Freelancer.com, Peopleperhour, Guru, Sribulancer, Projects.co.id, Fastwork, dan Microworkers) menggunakan web crawling, web scraping, dan ATC. Proses pengumpulan data pada penelitian tersebut memperoleh data berdasarkan informasi yang tertera pada akun penyedia jasa freelance marketplace, sedangkan untuk data yang tidak tersedia peneliti menggunakan perkiraan berdasarkan variabel lain. Hasil penelitian tersebut adalah profil pekerja gig economy jasa profesional Indonesia seperti freelance marketplace yang paling banyak digunakan, jenis jasa yang ditawarkan, dan penghasilan perbulan yang diperoleh dari kesembilan freelance marketplace tersebut [9]. Sementara Sinta Nur Asih meneliti mengenai faktor yang memotivasi pembeli jasa profesional Indonesia menggunakan UTAUT dan TAM. Pengumpulan data dilakukan melalui survei online yang memperoleh 133 data penduduk Indonesia yang pernah menggunakan jasa gig economy bidang jasa profesional. Penelitian menghasilkan temuan bahwa manfaat yang dirasakan dari gig economy dan pengaruh sosial 
merupakan faktor yang mendorong pembelian jasa oleh pengguna layanan gig economy jasa profesional [10].

Dalam penelitian ini, peneliti memperoleh data langsung dari pelaku gig economy bidang jasa profesional yang tidak terbatas pada pengguna freelance marketplace tertentu, serta yang menjadi perhatian tidak hanya freelance marketplace, namun juga melibatkan media sosial. Penelitian ini bertujuan memahami pemanfaatan freelance marketplace dan media sosial dalam perannya sebagai sarana aktivitas gig economy, khususnya untuk jual beli jasa profesional di Indonesia. Kedua jenis platform tersebut, tentunya memiliki perbedaan peran yang disebabkan oleh perbedaan fungsi utama dan cara kerja dari platform tersebut. Oleh karena itu, peneliti menggali peran masing-masing platform melalui proses perbandingan antara penggunaan kedua jenis platform. Melalui pemahaman tersebut, peran dari freelance marketplace dan media sosial sebagai wadah transaksi jual beli jasa keahlian dapat diketahui.

\section{METODE PENELITIAN}

\subsection{Pengumpulan Data}

Data yang digunakan dalam penelitian ini terdiri dari data demografi, seperti jenis kelamin, umur, domisili, sektor pekerjaan, dll, serta data pemanfaatan freelance marketplace dan media sosial oleh pelaku gig economy dalam sektor jual beli jasa profesional. Data dikumpulkan melalui survei/kuesioner Google Forms yang disebar secara umum dan dalam komunitaskomunitas jual beli jasa profesional Indonesia pada media sosial. Survei berhasil mengumpulkan sebanyak 280 data.

Tabel 1. Data responden survei

\begin{tabular}{|l|c|c|}
\hline \multicolumn{1}{|c|}{ Variabel } & Frekuensi & Persentase \\
\hline Umur & & \\
$<=19$ & 55 & 19.6 \\
$20-24$ & 126 & 45.0 \\
$25-30$ & 82 & 29.3 \\
$31-39$ & 15 & 5.4 \\
$>=40$ & 2 & 0.7 \\
\hline Jenis Kelamin & 105 & \\
Laki-laki & 175 & 37.5 \\
Perempuan & & 62.5 \\
\hline Domisili & 192 & \\
Jawa (Luar Jakarta) & 43 & 68.6 \\
Jakarta & 16 & 15.4 \\
Kalimantan & 12 & 5.7 \\
Sumatera & 7 & 4.3 \\
Sulawesi & 10 & 2.5 \\
Lainnya & & 3.6 \\
\hline Platform gig economy & 37 & 13.2 \\
Freelance marketplace & 92 & 32.9 \\
Media Sosial & 151 & 53.9 \\
Keduanya & $\mathbf{2 8 0}$ & $\mathbf{1 0 0}$ \\
\hline Jumlah
\end{tabular}

2.2 Metode Analisis

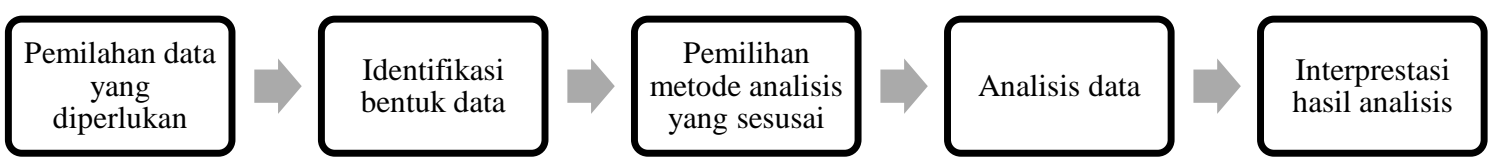

Gambar 1 Diagram proses analisis data

Metode analisis yang digunakan adalah descriptive statistical analysis dan inferential 
statistical analysis. Statistik deskriptif adalah metode yang mendeskripsikan dan menyimpulkan data secara logis dan efisien dalam bentuk teks berupa angka ataupun dalam bentuk grafik [11]. Metode ini digunakan untuk menghasilkan kesimpulan yang langsung didapat melalui pengamatan terhadap data. Sementara untuk inferential statistical analysis, tes yang digunakan adalah independent t-test, chi-square test, fisher's exact test, dan wilcoxon signed rank test. Uji statistik independent $t$-test bertujuan untuk menguji perbedaan mean antara dua sampel data yang independent [12]. Analisis ini digunakan untuk mengetahui apakah dua dataset berasal dari populasi yang sama atau dengan kata lain berhubungan satu sama lainnya. Chi-square test digunakan untuk mengetes hipotesis yang menyatakan bahwa tidak ada hubungan antara dua atau lebih kelompok, populasi, atau kriteria [13]. Fisher's exact test memiliki fungsi yang sama dengan chi square test, akan tetapi dapat digunakan untuk data yang lebih kecil. Chi-square test dan fisher's exact test sama-sama digunakan untuk data kategorikal. Sedangkan wilcoxon signed rank test berfungsi untuk membandingkan dua sampel yang berhubungan atau satu sampel yang mengalami pengukuran berulang.

Tabel 2 Daftar variabel dan metode analisis yang digunakan

\begin{tabular}{|l|l|l|}
\hline \multicolumn{1}{|c|}{ Nama Variabel } & \multicolumn{1}{|c|}{ Bentuk } & \multicolumn{1}{c|}{ Metode Analisis } \\
\hline Usia & Numerikal & Independent t-test \\
\hline Asal negara pembeli & Kategorikal & Chi-squared test \\
\hline $\begin{array}{l}\text { Penghasilan per-gig pengguna } \\
\text { FM sekaligus MS }\end{array}$ & Kategorikal yang berhubungan & $\begin{array}{l}\text { Wilcoxon signed rank test } \\
\text { untuk paired sample }\end{array}$ \\
\hline $\begin{array}{l}\text { Penghasilan per-gig pengguna } \\
\text { FM atau MS }\end{array}$ & $\begin{array}{l}\text { Kategorikal dengan jumlah } \\
\text { data kecil }\end{array}$ & Fisher's exact test \\
\hline $\begin{array}{l}\text { Jumlah gig perbulan pengguna } \\
\text { FM sekaligus MS }\end{array}$ & Kategorikal yang berhubungan & $\begin{array}{l}\text { Wilcoxon signed rank test } \\
\text { untuk paired sample }\end{array}$ \\
\hline $\begin{array}{l}\text { Jumlah gig perbulan pengguna } \\
\text { FM dan MS }\end{array}$ & $\begin{array}{l}\text { Kategorikal dengan jumlah } \\
\text { data kecil }\end{array}$ & Fisher's exact test \\
\hline Status pekerjaan gig economy & $\begin{array}{l}\text { Kategorikal dengan jumlah } \\
\text { data kecil }\end{array}$ & Fisher's exact test \\
\hline
\end{tabular}

Proses analisis inferensial dilakukan menggunakan bahasa pemrograman $\mathrm{R}$ 3.6.2 pada RStudio 1.2.5 menggunakan package stats [14].

\section{HASIL DAN PEMBAHASAN}

\subsection{Hasil Perbandingan Penggunaan Freelance Marketplace dan Media Sosial dalam Gig} Economy Jasa Profesional

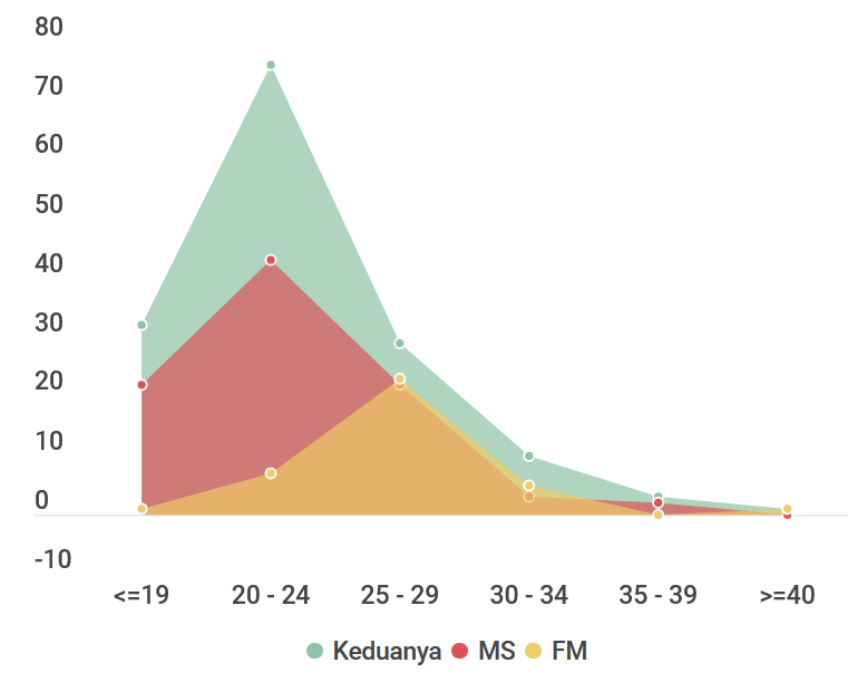

Gambar 2. Grafik usia pengguna freelance marketplace dan media sosial 
Rata-rata usia responden yang menggunakan hanya freelance marketplace adalah 26,7 tahun, lebih besar dibanding rata-rata usia pengguna media sosial saja dan pengguna kedua platform sekaligus, yaitu sama-sama sebesar 23,3 tahun. Gambar 2 menunjukan bahwa pengguna freelance marketplace saja paling banyak berada dalam kelompok usia 25-29 tahun, sementara pengguna media sosial dan pengguna kedua platform tersebut sekaligus paling banyak berada pada kelompok usia 20-24 tahun. Uji t-test dilakukan pada variabel umur dan penggunaan platform menghasilkan bahwa terdapat perbedaan yang signifikan antara usia pengguna freelance marketplace saja dan media sosial saja ( $p$-value < 0.001). Pengguna freelance marketplace cenderung berusia lebih tua dibandingkan pengguna media sosial

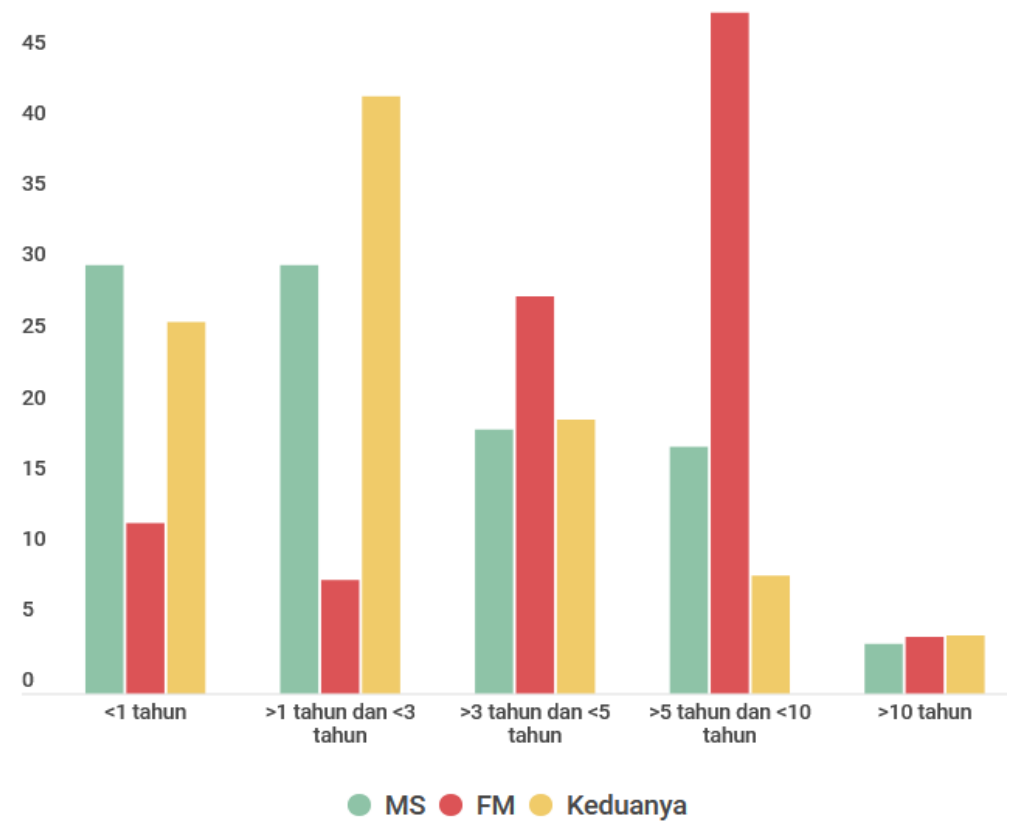

Gambar 3. Grafik lama berkarir dalam gig economy jasa profesional (dalam persen)

Gamber 3 menunjukan persentase lama berkarir dalam setiap jenis platform yang digunakan. Dari grafik dapat dilihat jika persentase jumlah pengguna freelance marketplace meningkat seiring dengan makin lamanya masa berkarir, sedangkan persentase pengguna media sosial semakin menurun. Hal ini, jika dikaitkan dengan usia pengguna kedua jenis platform tersebut, dapat menunjukan bahwa freelance marketplace cenderung digunakan oleh penyedia jasa yang lebih berpengalaman, sedangkan media sosial digunakan oleh penyedia jasa yang masih pemula.

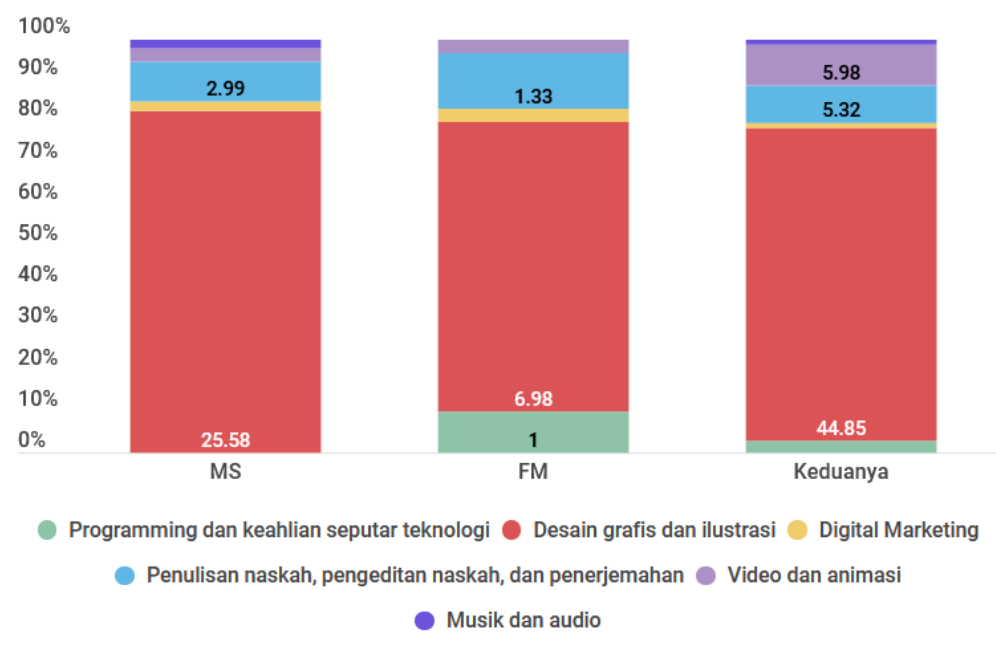

Gambar 4. Grafik jenis jasa yang dijual oleh penyedia jasa profesional Indonesia 
Dalam hal jenis jasa yang ditawarkan oleh penyedia jasa, desain dan Ilustrasi merupakan jenis jasa profesional yang paling banyak diperjual belikan oleh penyedia jasa profesional Indonesia baik pada freelance marketplace maupun media sosial seperti tampak pada Gambar 4.

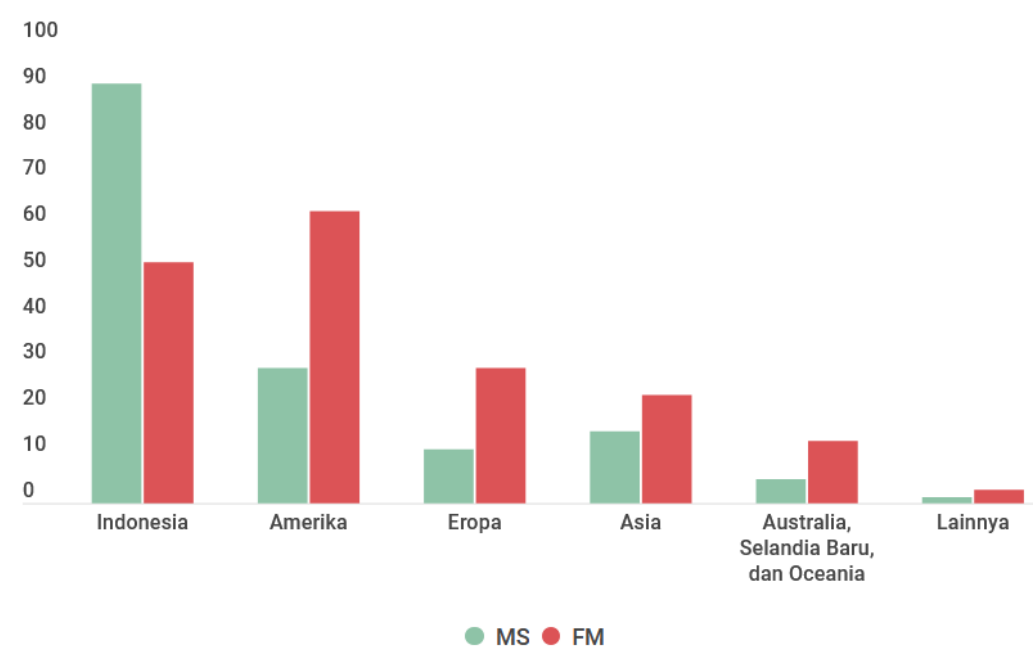

Gambar 5. Grafik persentase asal negara pembeli jasa profesional

Gambar 5 menunjukkan perbedaan pasar pada pengguna media sosial dan freelance marketplace. Pembeli jasa profesional pada media sosial lebih banyak berasal dari dalam negeri. Hal ini mungkin disebabkan oleh fungsi utama media sosial yang merupakan sarana untuk berkomunikasi, sehingga transaksi yang ada pada media sosial seringkali terjadi antar orang yang berada dalam lingkungan yang sejenis, dalam hal ini sama-sama berasal dari Indonesia. Selain itu adanya fitur group dalam media sosial tertentu membuat proses jual beli lebih terpusat diantara anggota grup tersebut. Chi-squared test dilakukan pada data pembeli jasa profesional untuk membandingkan pembeli dari Indonesia dan mancanegara. Tes menghasilkan perbedaan yang signifikan antara asal pembeli pada media sosial dan freelance marketplace ( -value $<0.001$ ). Pembeli jasa profesional pada media sosial cenderung berasal dari Indonesia, sedangkan freelance marketplace dari mancanegara.

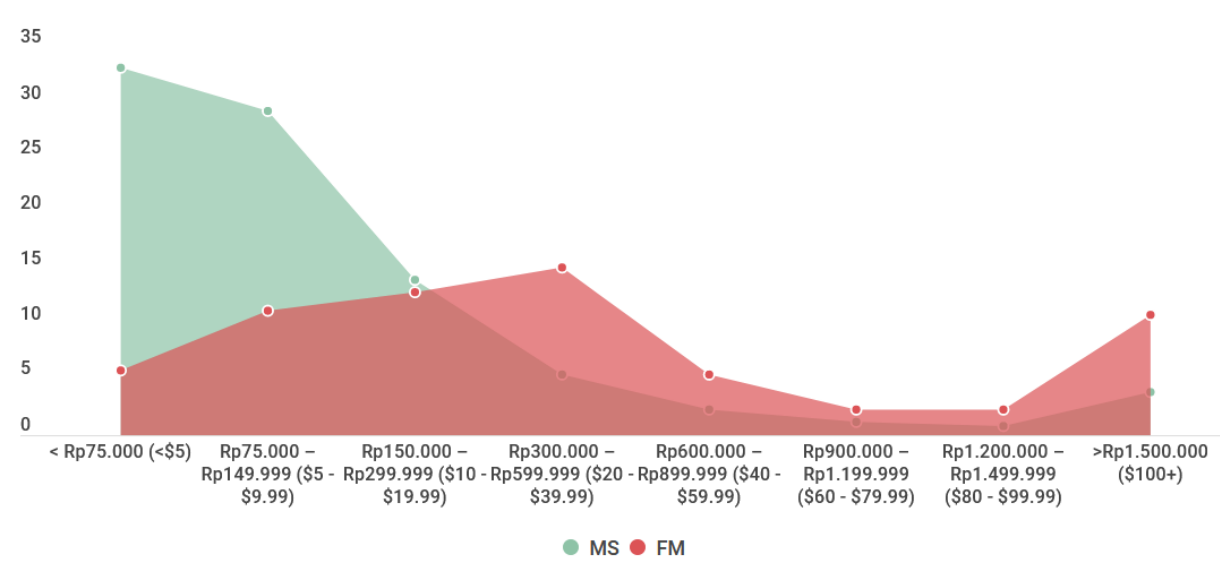

Gambar 6. Grafik penghasilan penyedia jasa profesional Indonesia per-gig (dalam persen)

Seperti ditunjukkan Gambar 6, pada media sosial, persentase jumlah penyedia jasa Indonesia dengan harga gig rendah lebih tinggi, sebaliknya harga gig penyedia jasa Indonesia pada freelance marketplace lebih bervariasi. Hal ini dapat menunjukkan bahwa harga jasa profesional pada media sosial tergolong lebih murah dibanding pada freelance marketplace. 


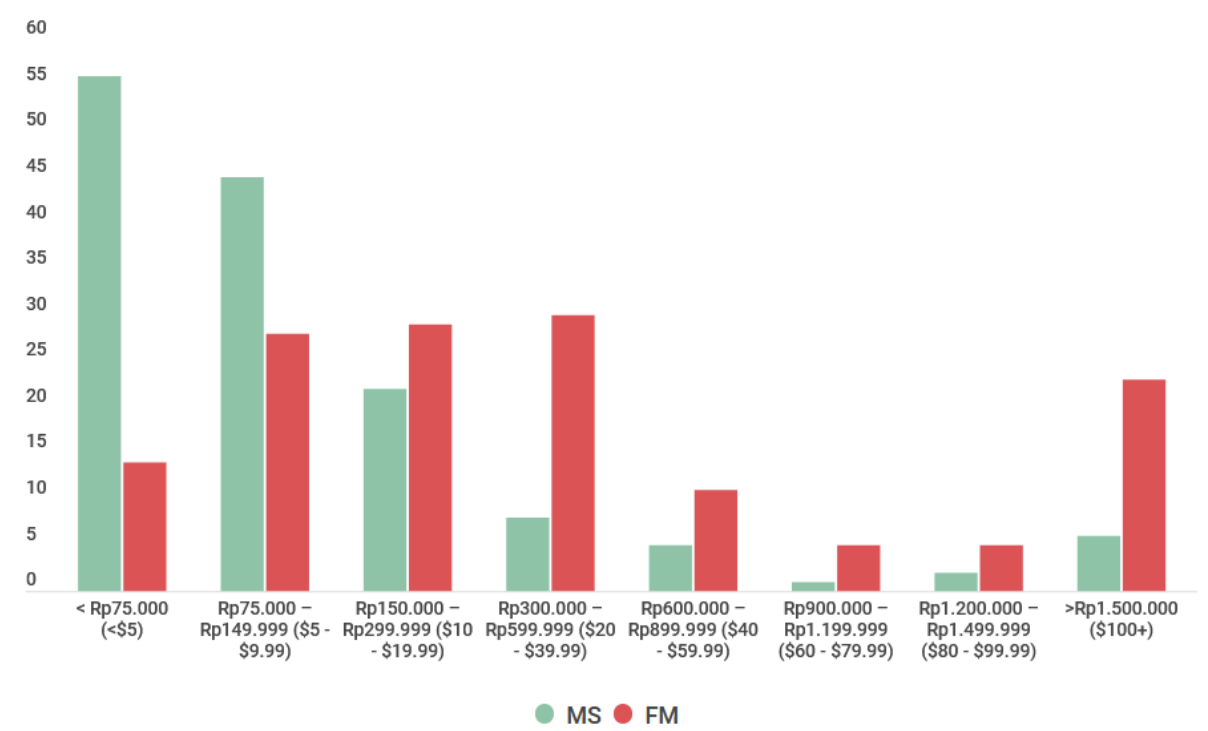

Gambar 7. Grafik rata-rata penghasilan penyedia jasa profesional pengguna media sosial sekaligus freelance marketplace

Untuk melihat perbedaan penghasilan per-gig dengan lebih jelas, peneliti membandingkan penghasilan per-gig milik penyedia jasa profesional Indonesia yang menggunakan kedua jenis platform sekaligus, yang diperoleh dari media sosial dan freelance marketplace. Gambar 7 menunjukkan perbedaan tarif yang diterapkan penyedia jasa profesional pada freelance marketplace dan media sosial. Hal tersebut dapat mengindikasikan penyedia jasa menjual jasanya dengan harga yang lebih murah di media sosial dibanding pada freelance marketplace. Selain itu terdapat juga kemungkinan jenis gig yang terjual pada media sosial lebih sederhana sehingga dihargai lebih rendah dibandingkan dengan gig pada freelance marketplace. Wilcoxon signed rank test untuk paired sample dilakukan pada data penghasilan per-gig pengguna media sosial sekaligus freelance marketplace. Peneliti juga melakukan uji statistik terhadap penghasilan per-gig dari penyedia jasa yang menggunakan freelance marketplace saja dan media sosial saja menggunakan Fisher's exact test. Hasil kedua tes membenarkan adanya perbedaan yang signifikan ( $\mathrm{p}$-value $<0,001)$ antara penghasilan pada kedua jenis platform.

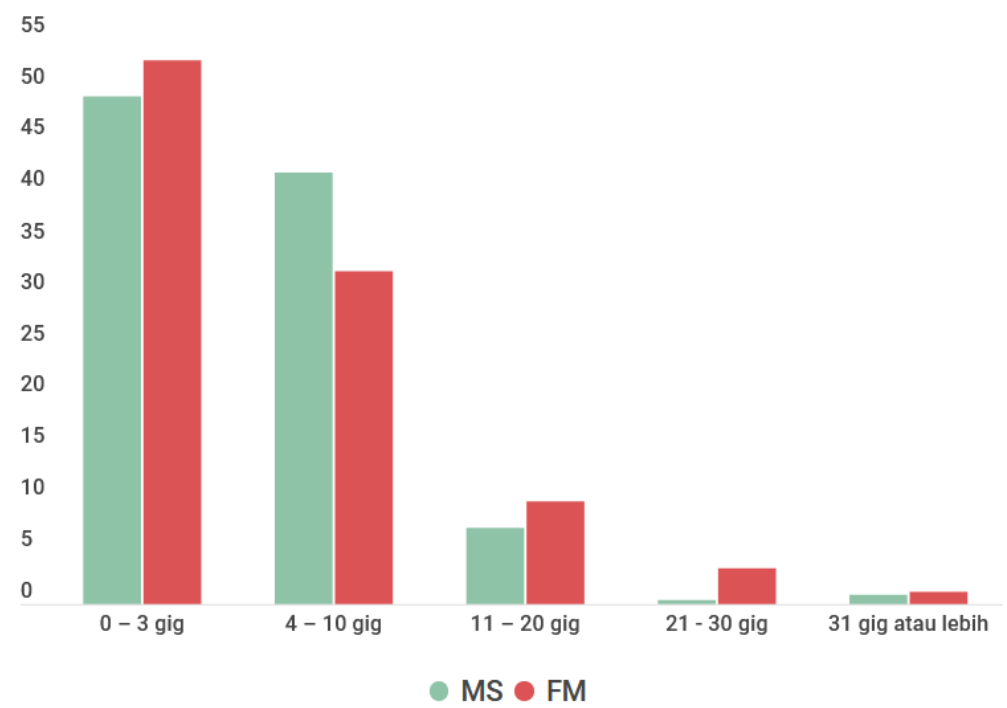

Gambar 8. Grafik rata-rata jumlah gig perbulan yang terjual pada freelance marketplace dan media sosial 
Gambar 8 menunjukan bahwa tidak terdapat perbedaan yang mencolok dalam jumlah gig yang terjual perbulannya, baik pada penyedia jasa profesional pengguna freelance marketplace maupun media sosial. Dalam pembelian jasa profesional juga tidak terdapat perbedaan mencolok antara kedua platform tersebut. Uji statistik Wilcoxon signed rank dan Fisher's exact test juga diterapkan pada data jumlah gig terjual perbulan bagi penyedia jasa profesional yang hanya menggunakan salah satu platform dan antar pengguna kedua platform sekaligus. Hasil tes menunjukan bahwa tidak ada perbedaan yang signifikan ( $p$-value $>0,1)$ antara jumlah gig yang terjual pada media sosial dan freelance marketplace.

\subsection{Peran Freelance Marketplace dan Media Sosial}

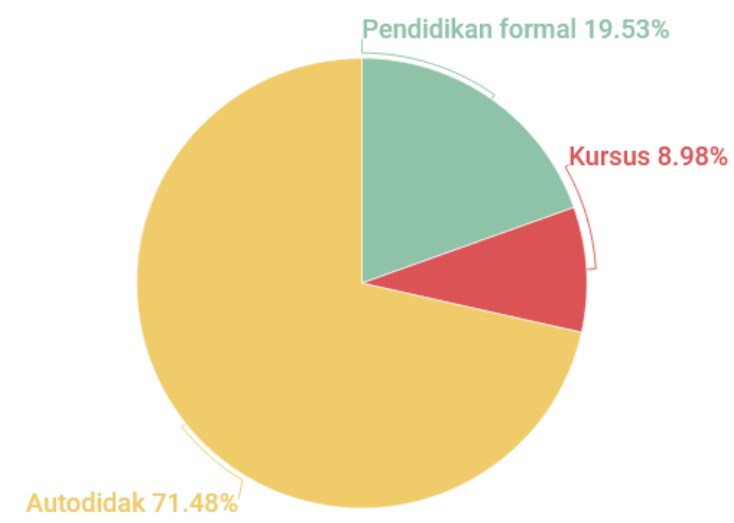

Gambar 9. Grafik asal keahlian penyedia jasa

Seperti ditunjukkan Gambar 9, mayoritas penyedia jasa memperoleh keahliannya hanya secara autodidak $(71 \%)$. Hal ini menunjukkan peran freelance marketplace dan media sosial yang dapat memberikan kesempatan kerja yang lebih luas kepada orang yang tidak atau belum memiliki gelar akademik untuk berkarir sesuai dengan jenis keahlian yang mereka miliki. Berbeda dengan lapangan kerja formal yang seringkali memiliki persyaratan berupa ijazah pendidikan formal atau pengalaman berkarir di bidang yang berkesesuaian. Freelance marketplace dan media sosial memberi kesempatan bagi penyedia jasa untuk dinilai murni dari keahliannya. Adapun jika dilihat dari platform-nya, tidak ada perbedaan yang mencolok antara pengguna media sosial maupun freelance marketplace, autodidak tetap merupakan asal perolehan keahlian dengan persentase tertinggi.

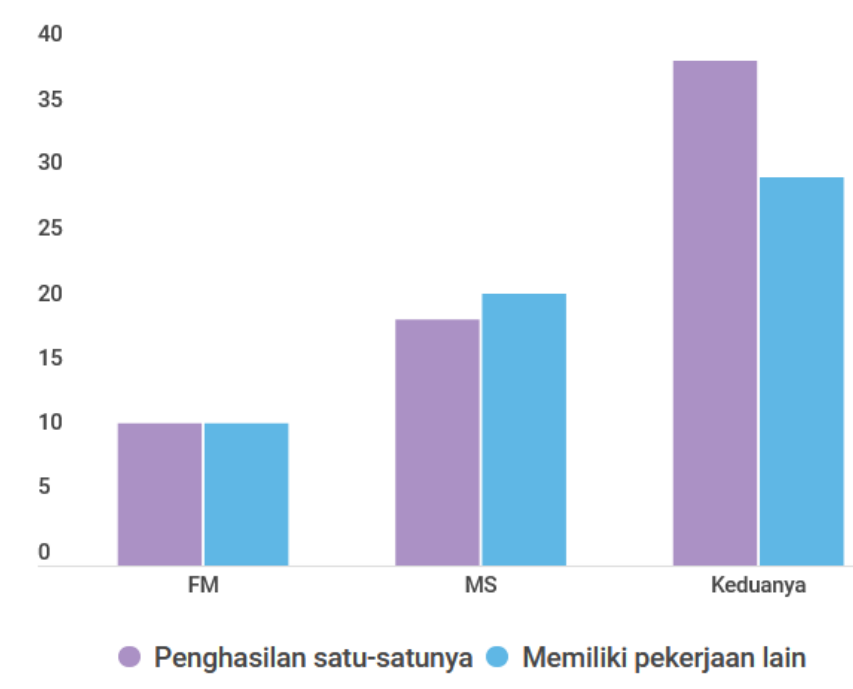

Gambar 10. Grafik status pekerjaan gig economy jasa profesional 
Berdasarkan status profesi, jika variabel usia dibatasi 23 tahun ke atas, dengan asumsi responden berusia tersebut tidak lagi berstatus pelajar dan sudah mandiri, terdapat $52,7 \%$ responden yang menjadikan profesi penyedia jasa profesional sebagai sumber penghasilan satusatunya seperti yang ditunjukkan pada Gambar 10. Dilihat dari platform yang digunakan, penyedia jasa yang hanya mengandalkan pekerjaan sebagai gig worker paling banyak menggunakan freelance marketplace dan media sosial sekaligus. Temuan ini dapat menunjukan bahwa freelance marketplace dan media sosial berpotensi berperan sebagai sarana untuk memenuhi kebutuhan hidup sebagai mata pencaharian utama. Perbandingan jumlah penyedia jasa profesional yang menjadikan profesi penyedia jasa sebagai penghasilan satu-satunya dan yang memiliki pekerjaan lain menggunakan fisher's exact test menghasilkan perbedaan yang tidak siginifikan ( $p$-value $=0,63)$. Hasil tersebut menunjukan tidak ada pengaruh antara penggunaan jenis platform dengan status pekerjaan penyedia jasa.

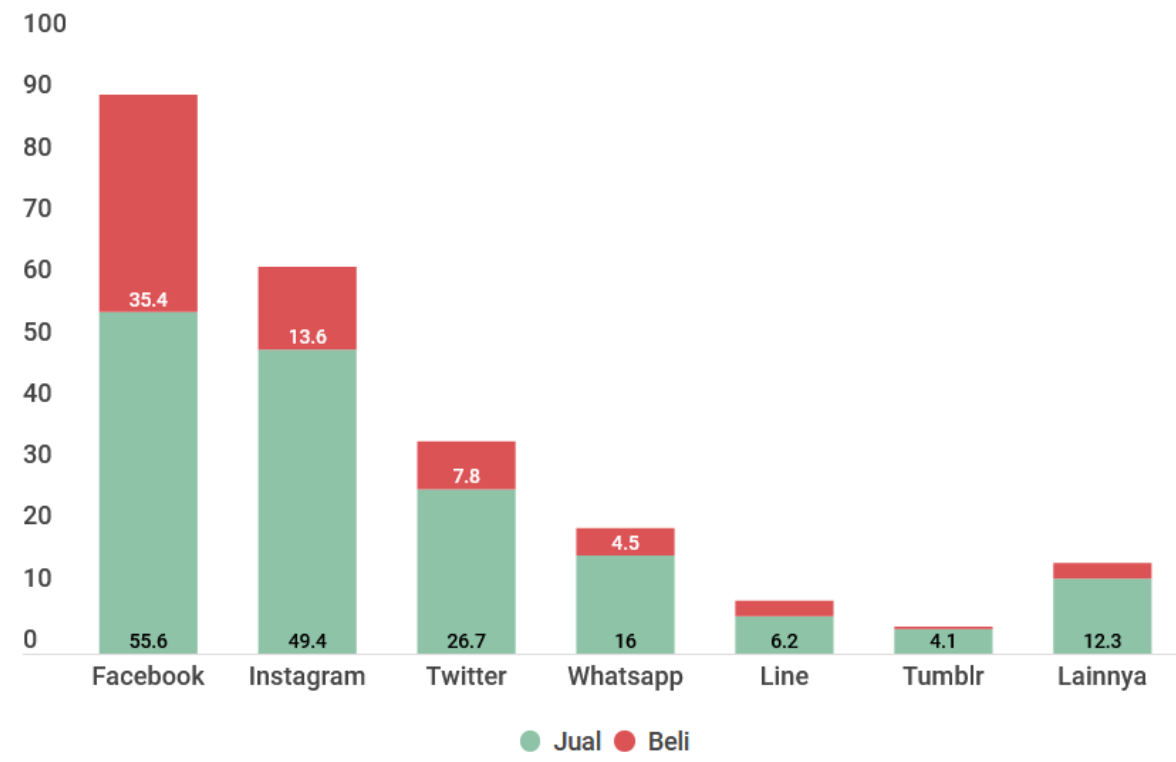

Gambar 11 Media sosial yang digunakan responden dalam kegiatan gig economy jasa profesional (dalam \%)

Fungsi utama media sosial yang merupakan sarana komunikasi, membuat media sosial lebih berperan dalam memasarkan jasa kepada orang yang berada dalam lingkungan pertemanan, dalam hal ini penduduk Indonesia. Media sosial telah berperan sebagai media jual beli jasa profesional bagi penyedia jasa yang tergolong masih pemula. Dengan media sosial, penyedia jasa dan pembeli jasa dapat berkomunikasi dengan lebih bebas. Karena pembeli pada media sosial kemungkinan besar merupakan orang yang berada dalam lingkungan, kultur budaya, serta bahasa yang sama, terlebih lagi jika kedua pihak tergabung dalam komunitas tertentu.

Gambar 11 menunjukkan media sosial Facebook, Instagram, dan Twitter sebagai media sosial yang paling banyak digunakan dalam gig economy jasa profesional, baik dalam kegiatan penjualan ataupun pembelian jasa. Popularitas Instagram dapat dipengaruhi oleh bidang kreatif yang menjadi jenis jasa yang paling diminati di Indonesia. Sedangkan Facebook dapat dikarenakan fitur group yang memungkinkan penyedia jasa dan pihak yang membutuhkan membentuk komunitas untuk memudahkan kegiatan jual beli. Grup Facebook memungkinkan penyedia jasa untuk mempromosikan jasa yang Ia jual tanpa perlu membangun follower seperti pada Instagram ataupun Twitter.

Dalam hal bertransaksi pun, melalui media sosial, pembeli dan penyedia jasa dapat memilih sendiri alur transaksi sesuai kesepatakan bersama, berbeda dengan freelance marketplace yang sudah memiliki peraturan yang baku, yang mungkin akan menyulitkan bagi penyedia jasa pemula. Media sosial juga memberikan kebebasan bagi penyedia jasa untuk 
memilih metode pembayaran sesuai dengan kebutuhannya. Karena jual beli pada media sosial lebih banyak yang bersifat lokal, pembayaran dapat dilakukan melalui transfer bank lokal, ewallet, pulsa dan lain-lain. Hal ini tentu dapat membantu penyedia jasa yang membutuhkan dana cepat ataupun yang tidak memiliki akses terhadap sistem transaksi internasional.

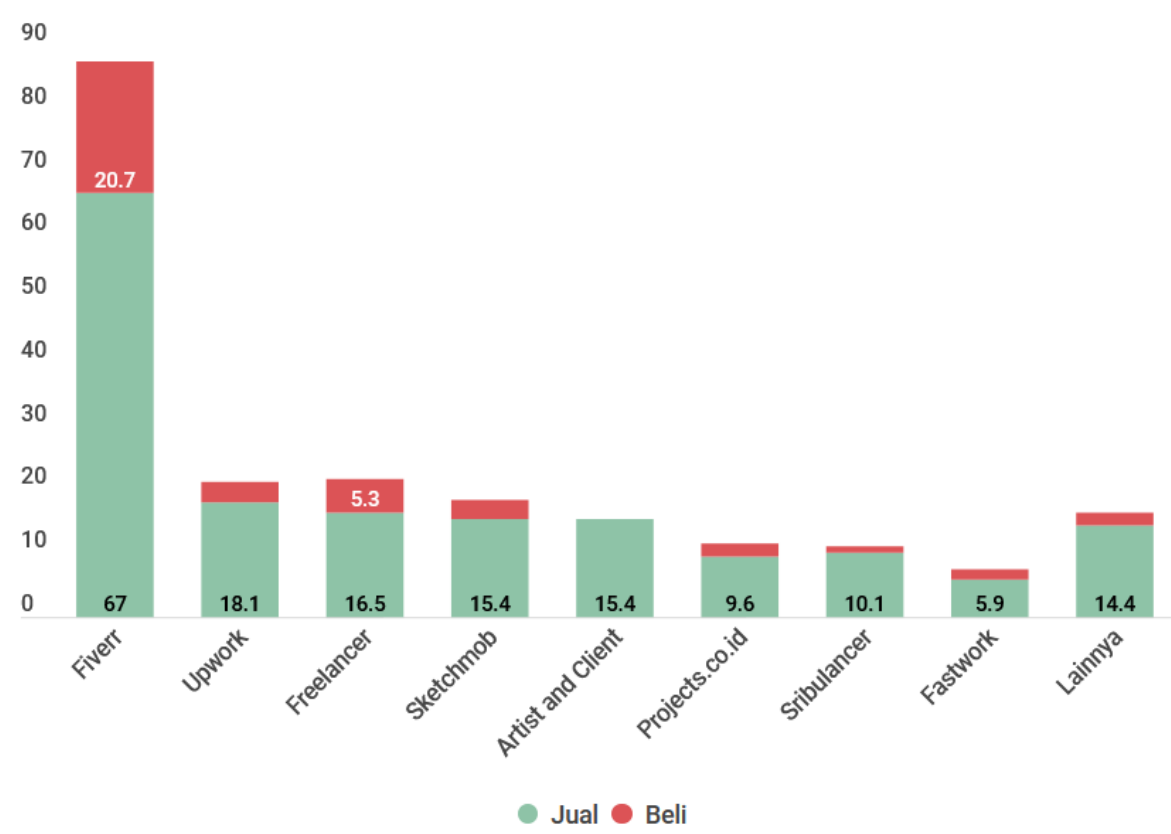

Gambar 12 Freelance marketplace yang digunakan responden dalam kegiatan gig economy jasa profesional (dalam \%)

Gambar 12 menunjukkan bahwa Fiverr merupakan freelance marketplace yang paling banyak digunakan oleh penyedia maupun pembeli jasa profesional Indonesia. Hal ini dapat disebabkan oleh kemudahan cara kerja Fiverr. Kepopulerannya di Indonesia juga dapat ikut andil dalam besarnya persentase pengguna Fiverr, penyedia jasa yang telah sukses di platform tersebut dapat memberikan pengaruh kepada rekan seprofesinya sehingga mereka tertarik menggunakan Fiverr juga. Bidang kreatif sebagai jasa profesional yang paling diminati oleh penyedia dan pembeli jasa Indonesia juga memberikan pengaruh terhadap jenis freelance marketplace yang digunakan. Pada Gambar 12, freelance marketplace khusus ilustrasi seperti Sketchmob dan Artist and Client memiliki cukup banyak pengguna. Berdasarkan asal pembeli jasa, freelance marketplace berperan dalam memperluas pemasaran jasa penyedia jasa profesional Indonesia di mancanegara. Dengan memasarkan jasa tanpa dibatasi faktor geografis, penyedia jasa berkesempatan untuk mendapatkan lebih banyak pembeli dengan bayaran yang lebih tinggi. Walaupun media sosial juga tidak menutup kemungkinan menjadi sarana pemasaran ke luar Indonesia, akan tetapi cara kerja freelance marketplace yang dikhususkan sebagai wadah jual beli jasa profesional, membuat jasa yang ditawarkan pada platform tersebut menjadi lebih dikenal oleh calon pembeli dari berbagai tempat.

Perbedaan pasar pada freelance marketplace dan media sosial juga berperan dalam menyebabkan perbedaan penghasilan yang didapat penyedia jasa profesional. Perbedaan nilai mata uang Indonesia dan negara lain dapat membuat suatu jasa dihargai lebih dibandingkan di pasar lokal. Penghasilan penyedia jasa juga dapat dipengaruhi oleh perbedaan bentuk permintaan dari klien. Terdapat kemungkinan bahwa kebutuhan pembeli pada freelance marketplace lebih kompleks dibandingkan pembeli pada media sosial yang menyebabkan lebih besarnya harga suatu jasa pada freelance marketplace. 


\section{KESIMPULAN DAN SARAN}

Walaupun memiliki fungsi yang berbeda media sosial dan freelance marketplace, samasama telah dimanfaatkan sebagai media jual beli jasa profesional lepas dalam gig economy. Beberapa perbedaan yang dimiliki kedua jenis platform ini menghasilkan perbedaan pula dalam perannya. Freelance marketplace selaku media yang memang diciptakan khusus sebagai sarana jual beli gig, berperan dalam memperluas jangkauan pemasaran jasa penyedia jasa profesional Indonesia ke mancanegara. Freelance marketplace juga telah menjadi wadah jual beli yang cocok bagi penyedia jasa profesional yang sudah serius mendalami karir ini, dinilai dari tingginya penghasilan yang mungkin didapat per-gignya. Sedangkan media sosial, walaupun jual beli bukan merupakan fungsi utamanya, dapat dimanfaatkan sebagai sarana pemasaran jasa profesional yang cukup baik. Media sosial telah berperan sebagai sarana pemasaran jasa kepada pembeli dalam negeri. Sifat transaksi media sosial yang tidak baku membuatnya cocok untuk penyedia jasa yang masih pemula, walaupun penghasilan per-gig yang didapat lebih kecil dibanding freelance marketplace. Di luar perbedaan-perbedaan tersebut, freelance marketplace dan media sosial memiliki kesamaan dalam perannya sebagai sarana jual beli jasa profesional yang berpotensi membantu, bahkan menyokong perekonomian gig worker Indonesia. Freelance marketplace dan media sosial telah membantu membuka lapangan kerja baru bagi pemilik skill, terlebih lagi dalam bidang kreatif seperti desain grafis dan ilustrasi.

Hasil dari penelitian ini tentu saja sangat dipengaruhi oleh sebaran data yang diperoleh. Meski kecil, masih terdapat kemungkinan ada segelintir gig worker di Indonesia yang tidak aktif di komunitas-komunitas jual beli jasa profesional Indonesia pada media sosial sehingga belum terjangkau oleh penelitian ini. Selain itu, jenis media sosial yang digunakan dalam menyebarkan kuesioner tersebut tentu saja juga dapat berpengaruh atas sebaran data yang dikumpulkan. Untuk mengatasi hal ini, penelitian selanjutnya dapat dilakukan dengan skala yang lebih besar dengan memperbanyak media penyebaran kuesioner dan tidak terbatas hanya pada media sosial populer saja. Selain itu, penelitian lanjutan dalam bentuk kualitatif seperti etnografi di mana peneliti harus turut bergabung dalam komunitas-komunitas gig economy jasa profesional tersebut, juga dapat memperkaya dan memperdalam pemahaman terkait lika-liku gig economy jasa profesional di Indonesia.

\section{DAFTAR PUSTAKA}

[1]. Saputera, F. L, 2020, Dampak Virus Korona : 1,7 Juta Orang Kehilangan Pekerjaan akibat Covid-19. KOMPAS. id: https://kompas.id/baca/ekonomi/2020/05/04/17-juta-orangkehilangan-pekerjaan/, diakses tanggal 21 Oktober 2020.

[2]. Signes, A. T, 2017, The 'Gig Economy': Employee, Self-employed or the Need for a Special Employment Regulation?, SAGEPUB, hal 1-13.

[3]. Rouse, M, 2019, Gig Economy, WhatIs.com: https://whatis.techtarget.com/definition/gig-economy, diakses tanggal 18 Oktober 2020.

[4]. Shankar, V., Inman, J., Mantrala, M., Kelley, E., \& Rizley, R, 2011, Innovations in Shopper Marketing: Current Insights and Future Research Issues. Journal of Retailing, hal 14.

[5]. Robinson, S, 2016, The Freelancers Roadmap, Creativelive: https://www.creativelive.com/blog/wp-content/uploads/2016/03/The-Freelancers-

Roadmap-by-CreativeLive.pdf, diakses tanggal 20 Oktober 2020

[6]. Auditianto, A., Sucahyo, G. Y., Gandhi, A., \& Ruldeviyani, Y, 2019, Discovering the Influencing Factors of Physical Gig Economy Usage : Quantitative Approach on Clients' Perception, ICACSIS 2019, hal 357-362.

[7]. Fatmawati, D., Isbah, F., \& Kusumaningtyas, A. P, 2019, Pekerja Muda dan Ancaman 
Deskilling-Skill Trap di Sektor Transportasi Berbasis Daring. Jurnal Studi Pemuda.

[8]. Kibaroğlu, O, 2018, The Agile Perantau \& The Perpetual Gig Economy: A Genealogy of the Pengojek, Disertasi, Faculty of Arts and Social Sciences National University of Singapore, Singapura.

[9]. Faisal, A. F., Sucahyo, Y. G., Ruldeviyani, Y., \& Gandhi, A, 2019, Discovering Indonesian Digital Workers in Online Gig Economy Platforms, ICOIACT, hal 554-559.

[10]. Asih, S. N., Sucahyo, Y. G., Gandhi, A., \& Ruldeviyani, Y, 2019, Inhibiting Motivating Factors on Online Gig Economy Client in Indonesia, ICACSIS, hal 349-356.

[11]. Vetter, T, 2017, Descriptive Statistics: Reporting the Answers to the 5 Basic Questions of Who, What, Why, When, Where, and a Sixth, So What?, Anesthesia \& Analgesia: November 2017, Volume 125 - Issue 5, hal 1797-1802.

[12]. Kim, T. K, 2015, T-test as a Parametric Statistic, Korean Journal of Anesthesiology, hal 540-546.

[13]. Rana, R., \& Singhal, R, 2015, Chi square Test and its Application in Hypothesis Testing, Journal of the Practice of Cardiovascular Sciences, hal 69-71.

[14]. R Core Team, 2019, R: A language and environment for statistical computing. R Foundation for Statistical Computing, Vienna, Austria. https://www.R-project.org/. 